\title{
Investigating the Teachers' Innovative Pedagogical Practices towards Students with Special Needs
}

\author{
Sedef SÜER ${ }^{1}$ Özlem ALTINDAĞ KUMAŞ² Arzu KARAGÜL ${ }^{3}$
}

\begin{abstract}
This study aims to investigate the views of teachers working with students with special needs towards innovative pedagogy practices. In this context, the purpose of teachers' using of innovative pedagogical practices and various problems faced by teachers when they use innovative practices, were also handled in this study. The study was based on the descriptive survey method and qualitative data was collected. The study was conducted with 34 teachers working with individuals with special needs who were selected for the study with the maximum variation sampling method. The data were collected through the "Innovative Pedagogy Interview Form" and analyzed with descriptive analysis technique. Findings showed that teachers working with individuals with special needs mostly define themselves as innovative and design their teaching process with various materials considering the students' interests and needs. However, it was determined that they faced various problems such as inadequate equipment and materials, insufficient learning environment, and inadequate level of teacher readiness and quality.
\end{abstract}

Keywords: Innovative pedagogy; Innovative practices; Students with special needs; Special education teachers

\section{INTRODUCTION}

\section{Introduce the problem}

Innovation is a thought, practice, or purpose perceived as new by an individual (Rogers, 1995). Innovation can be a new idea created by an individual, or it can be in the form of adopting a previously known concept to a different field of study (Furst-Bowe \& Bauer, 2007; White \& Glickman, 2007). Whether an idea is used by the individual for the first time or the implementation of an existing idea, both of them are accepted as innovation (Rogers, 1995). The main goal of innovation is to do something different and better (Redding, Murphy \& Twyman, 2013). In the social life cycle, people may not agree on innovation due to their characteristics too. Depending on this differentiation, the concept of individual innovativeness come into view (Yorulmaz, Çokçalışkan \& Önal, 2017). As this conception can encompass everyone, the teachers who are the leading actors in education can be involved as well. And this often leads the innovativeness and pedagogy concepts to be used together.

Many experts are confused about it when the definition of the pedagogy as a concept is analyzed (Murphy, 2008). In the most general sense pedagogy, defined as the act of transferring knowledge, values, and skills is not limited to formal education context and can be applied to formal and informal contexts by parenting and various other experts. (Edwards, 2001). With this expression, the primary pedagogical issues are said to be as follows: "How to educate a child? How to improve children's learning and how to meet their learning needs?" (Murphy, 2008). Therefore, educational goals and strategies or educational methods determined by students and teachers, educators 'own philosophical beliefs, students' background knowledge and experience, educational programs, modern technological devices, monitoring, and evaluation system are accepted as the main tools of pedagogical education (Smith, 2012).

\footnotetext{
${ }^{1}$ Dicle Üniversitesi, Türkiye, sedefsuer@gmail.com, ORCID: 0000-0002-1833-9286

2 Dicle Üniversitesi, Türkiye, ozlemmaltindag@gmail.com, ORCID: 0000-0002-6104-2381

${ }^{3}$ Dicle Üniversitesi, Türkiye, arzukaragul12@gmail.com, ORCID: 0000-0003-0670-7050
} 
It is known that the quality of the education system depends on the quality of its teachers. So that students can deal with the challenges of the modern world, teachers need to review and update their pedagogies (OECD, 2020). Application-level updating, or innovation should be seen as a normal process of the daily challenges of a constantly changing class. Innovative pedagogy, which is the pedagogical reflection of innovation; is a pedagogical problem-solving process based on the creative, intuitive, and personal capacities of teachers (Braun \& Schmidt, 2006). The primary questions of innovative pedagogy are: What are the educational, psychological, organisational factors/conditions that have the highest formative effect on an individual's mind, character, or physical ability? What can be done with the curriculum and technology? Which educational method is sustainable for our environment? (Boyle, 2013). As a consequence, innovative pedagogy as a science and practice is responsible for educating individuals to be creative, to deal with changes, to manage the knowledge, to analyze and work with knowledge (Murphy, 2008). Innovative teachers, on the other hand, are those who can enhance their skills by following the latest developments in their profession, can effectively integrate technological tools into educational environments, can increase the number of activities that students can participate in, may try new approaches and ways in the presentation of information, may apply different methods to increase student participation and may change their habits to bring new skills to life (Rawlins \& Kehrwald, 2013). Teachers should have innovative features due to reasons such as new technological developments, new curricula, new learning and teaching methods, new skills that society expects from the individual, and changes in student needs (Ritchhart, 2004).

In terms of special education, innovative pedagogy is seen as an application that allows a student with special needs to compete at the same level as their normally developed peers (Boyle 2013). In other words, innovative pedagogy enables students with special needs not only to enhance their educational success but also to take advantage of the education that they get (Murphy, 2008). It cannot be expected that all the students can learn similarly and at the same speed. Therefore, it is important to supply a wide range of learning materials while providing tools for students to learn (Braun \& Schmidt, 2006). Innovative pedagogical practices in the field of special education are stated to involve various technological applications such as smart pens and tablet apps, audial reading technology which is preferred to be used with the repetitive reading strategy for the students with reading difficulties, the use of evidence-based practices for the students with special needs, Braille writing tablet used for visually handicapped students, and visual materials used for the hearing impaired students (Murphy et al., 2013). Using such tools provides to the students with special needs to learn without a special program (Dillon, 2006). Therefore, it is of vital importance to use these tools in educating the handicapped students who have to take the same exams with their normally developed peers (Boyle 2013). In this way, it is stated that students can easily develop more positive self-esteem and the skills to be successful after graduation (Murphy et al., 2013). Such practices have an important role for the mentally handicapped individuals in that they can live more independently in society. The related studies in the literature also reported that the social and academic skills of the students with special needs have improved with the use of innovative pedagogical practices and applications in education (Pratt, 1999; Will, 1986).

An educational approach, designed with innovative pedagogy, certainly cannot be the only factor in solving many problems in today's world. However, it plays a significant role in changing perspectives of the upcoming generations (Kovacs, 2017). This statement is for all students including those with special needs. The use of technology and evidence-based practices in education, especially in the concept of innovative pedagogy, make the education process more 
exciting for students with special needs (Pratt, 1999). Therefore, teachers need to search such practices and design innovative activities that will contribute to students with special needs. Meyen, Poggio, Seok and Smith (2006) stated that the use of innovative pedagogical practices in the assessment of academic skills of students with special needs is also important in preventing inequality between students and their peers. Innovative pedagogy plays an important role in contributing not only the learning of the students with special needs but also the teaching skills of teachers. Therefore, teachers should possess some kind of properties which support the development and participation of students (Güner-Yıldız \& Sazak-Pınar, 2012) and these teachers, known to have the most preliminary role in the training of students with special needs, should be aware of innovative pedagogy. In the literature, some studies analyzed the innovative pedagogical practices of teachers and preservice teachers in terms of different variables (Blackhurst 2005; Erdogan \& Güneş, 2013; Hasselbring \& Glaser, 2000; Kert \& Tekdal, 2012; Öztürk \& Summak, 2014; Parlar \& Cansoy, 2017). However, the studies investigating the innovative pedagogical practices of teachers working in the field of special education are quite limited.

The innovative pedagogical practices of teachers working with students with special needs are of great value in that it contributes to both designing of learning activities that address individual differences of students and maximizing the potential of these children. Innovative pedagogy, on one hand, allows teachers and students to achieve maximum efficiency from learning and teaching processes, on the other hand, enable them to use technology-based methods to build knowledge (Edwards \& Bone, 2012). Therefore, this study will provide important information regarding whether teachers' working with students with special needs use innovative pedagogical practices in their classrooms, determining the reasons for using innovative pedagogical practices and what kind of problems they have when using innovative pedagogical practices. Thanks to the results of this study, the teachers working with students with special needs are thought to access the chance of making self-evaluation about their practices, discovering the pros and cons of their teaching process while decision-makers are thought to access the valid and reliable data on this issue. This study is also thought to contribute to the understanding of teachers or preservice teachers who are working or will work with students with special needs. In line with this, this study aims to investigate the innovative pedagogical practices of teachers working with students with special needs. In this context following questions were investigated: The body of a manuscript opens with an introduction that presents the specific problem under study and describes the research strategy. Because the introduction is clearly identified by its position in the manuscript, it does not carry a heading labeling it the introduction. Before writing the introduction, consider the following questions:

What are the motives of teachers working with individuals with special needs to perceive themselves as innovative?

For what purposes and reasons do teachers working with individuals with special needs apply innovative pedagogical practices?

What kind of problems do teachers working with individuals with special needs deal with while applying innovative pedagogical practices?

\section{METHOD}

This section includes information about the research design, study group, data collection and analysis process. 


\section{Study Design}

This study was carried out with a descriptive survey model, method, which is one of the descriptive research types. The survey model is a scientific method used to investigate the particular property of a group (Büyüköztürk, Kılıç-Çakmak, Akgün, Karadeniz \& Demirel, 2013). Survey studies use principles of the scientific method by examining existing resources, analyzing the data, making generalizations and predictions. Research conducted in a survey model is called the descriptive survey method if it examines the conditions, practices, processes, beliefs, relationships, and tendencies of an existing phenomenon. Both qualitative and quantitative data can be used in the descriptive survey method (Salaria, 2012). This study investigating the views of teachers working with individuals with special needs towards innovative pedagogy practices was designed on the descriptive survey method as it focuses on describing views of teachers working with individuals with special needs, which is a specific feature of teachers as a certain group. For this reason, the study in question was conducted with the descriptive survey model in which qualitative data was collected.

\section{Study Group and Participants}

This study was conducted with 34 volunteer teachers working with individuals with special needs. Participants were selected among teachers who work in the hearing difficulty, visual difficulty, and education practice schools in Diyarbakır city center. Firstly the three schools were visited separately, an appointment day was determined for teachers who volunteered to participate in the study, and approval was requested from the school administration for data collection. In the selection of the participants, the maximum diversity sampling method was used, as attention was paid to the diversity of teachers working in institutions providing education for students with special needs in terms of gender, seniority, and school type variables. Maximum variation sampling is a method which requires to set certain criteria for the participants to be included before the research and requires to involve these participants under these criteria, in this way it obtains different perspectives on the subject to be researched (Creswell, 2017). The descriptive properties of the participants included in the study are shown in Table 1.

Table 1. Descriptive Properties of The Participants Included In The Study

\begin{tabular}{lll}
\hline Gender & $\mathbf{N}$ & $\mathbf{\%}$ \\
\hline Female & 15 & 44.1 \\
Male & 19 & 55.9 \\
\hline Seniority & $\mathbf{N}$ & $\mathbf{\%}$ \\
\hline $1-5$ years & 4 & 11.8 \\
$6-10$ years & 9 & 26,5 \\
$11-15$ years & 4 & 11.8 \\
$16-20$ years & 4 & 11.8 \\
21 or above years & 13 & 38.2 \\
\hline
\end{tabular}




\begin{tabular}{lll}
\hline School type & N & \% \\
\hline School for students with hearing difficulty & 16 & 47.1 \\
School for students with visual difficulty & 11 & 32.4 \\
School for students with mental retardation & 7 & 20.6 \\
\hline
\end{tabular}

In this research, the teachers were selected based on variations by gender, seniority, and school types. The participant teachers in this study were determined to be male $(\mathrm{N}=19)$, teaching to individuals with hearing difficulty $(\mathrm{N}=16)$, and having 21 years or more professional experience $(\mathrm{N}=13)$.

\section{Data Collection Tool and Instrument}

The Innovative Pedagogy Interview Form for Teachers developed by Suer (2019) was applied to participants. The original form consists of a personal information section consisting of five questions and two open-ended questions. The Innovative Pedagogy Interview Form was not used as it is. While the questions related to the participants' personal information were appropriately revised in line with the context of the study, the interview questions were used as it is. On the other hand, one question was added in accordance with the context of the study. The revised form was sent to 3 experts (in the fields of educational science, special education science, and language education), as a result of the feedback received from the experts, the form was used as it is. The interview form comprised of 3 descriptive and 3 open-ended questions were applied to teachers working with individuals with special needs. The questions in the interview form are as follows:

- As a teacher, could you describe yourself as innovative, why? Please explain your opinions on this matter with your reasons. (Please answer this question by explaining which feature, skill, or ability you use the most while making innovative applications in the education process).

- Do you use innovations in education in your classroom? (such as trying or developing different technologies, methods, and materials while teaching a subject). Please write down your views on why you need this with justifications.

- What do you think are the most important problems you encounter while implementing innovative applications in your classroom in the educational environment? Please write with the reasons.

\section{Data Collection Process}

The data collection process began with the specifying of school types (including hearing difficulty, visual difficulty, and mental retardation) which provide education for individuals with special needs in the center of Diyarbakir. Some explanations regarding the questions in the questionnaire form were made to the participant teachers via face to face interactions. Then, each participant teacher was given an "Innovative Pedagogy Interview Form for Teachers" and allowed as much time as they wanted to write their opinions in handwriting in the space allocated for each question on the form. During data collection, teachers were asked to provide as much data as they wanted by filling out the form with their own handwriting so that they could reflect on each question in detail and express their opinions more easily. Moreover, the participant teachers voluntarily participated in this study, and they were not asked to give any personal information revealing their identity during the research, and the teachers were assured to have the right of leaving the 
study at any stage if they wished. As a result, all 34 teachers who participated in the research voluntarily filled out the form and did not request to withdraw from the research at any stage of the study.

\section{Data Analysis and Interpretation}

In this study, the qualitative data obtained from the teachers were analyzed by descriptive analysis method. Descriptive analysis is a method focusing on the interpretation of the research data based on the themes and dimensions revealed by the research questions, by directly quoting from the data suitable for relevant themes and dimensions in a qualitative data material (Ekiz, 2009; Yıldırım \& Şimşek, 2011).

The interview form that obtained from 34 participant teachers primarily were numbered as $\mathrm{T} 1, \mathrm{~T} 2$, T3.......T34 by the researchers. A word file was opened on the computer with the same numbers for each participant teachers and their views on the sheet were numerically transferred to the related file. With recording the data on the computer, the views of participants about each interview question have been read one by one, and notes and coloring procedures were adopted by the three researchers. To classify and identify the data results of the first analysis, codes were determined and each code was placed and interpreted under the theme in the context of research questions. Then the data obtained as a result of analysis were tested for validity.

Validity refers to the degree of reflecting the reality of the data in qualitative studies (Silverman, 2000). To provide the validity in this research, the questions in the data collection tool were prepared within the scope of the related studies in the literature and detailed information about the study group was presented (Miles, Huberman \& Saldana, 2014). The analyst triangulation method was used to provide validity in the analysis of data and the analyses were carried out by 2 experts, one of in the field of educational sciences and the other in the field of special education. At the end of this process the themes and views of the teachers related to the data were determined to show consistency and the themes were concluded to be supported by the related literature. Besides, to provide coding consistency among the researchers, the formula of Percentage of Consensus $=$ Agreement $/(\text { Agreement }+ \text { Disagreement })^{*}$ which was proposed by Miles and Huberman (1994: 64) was applied to randomly 50 selected codes. The calculated coding reliability of the data was found as 93 .

The reliability in the qualitative studies can be provided by providing detailed information and explanation about processes such as data collection, analysis, and reporting (Büyüköztürk, KılıçÇakmak, Akgün, Karadeniz \& Demirel, 2013). In this sense, the interviews with participant teachers were carried out by allocating time in their schools, the volunteer participation was taken as the basis for the selection of the participants, enough time was given to the participant teachers to fill-up the form, and the data collection process was completed when the data reached the repletion process.

\section{RESULTS}

In this section, in parallel with the research questions, findings on the what kind of indicators were put forward by teachers working with individuals with special needs towards being innovative, for what purposes they use innovations in the educational environment, and what kind of problems they encounter while using innovations in the educational environment were presented.

\section{Indicators of Teachers for Describing Themselves Innovative}


Teachers working with individuals with special needs were asked whether they see themselves as innovators, and if teachers see themselves as innovators, they were asked to identify the indicators of their describing themselves as innovators. In this context, the majority of the teachers stated that they see themselves as innovative (Shown in Table 2), and then the indicators are shown as the basis for describing themselves as innovators were examined, and the findings obtained were given in Figure 1 under five main themes.

Table 2. Findings Regarding Whether Teachers Working with Special Needs Identify Themselves as Innovative

\begin{tabular}{lll}
\hline & $\mathbf{n}$ & $\mathbf{\%}$ \\
\hline I identify myself as innovative & 32 & 94.12 \\
I do not identify myself as innovative & 1 & 2.94 \\
I am indecisive about whether I am innovative or not & 1 & 2.94 \\
\hline Total & 34 & 100 \\
\hline
\end{tabular}

When the findings are examined, the vast majority of the teachers $(n=32)$ stated that they see themselves as innovators, while a very small portion of them said that they were not innovative (n $=1$ ) or they were indecisive about whether they were innovative or not $(n=1)$. Some of the teachers' views on this are as follows:

I can identify myself as innovative, but I am just starting so I cannot react immediately to this [T4].

As a teacher, of course, I identify myself as an innovator [T14].

I can identify myself as an innovator [T24].

When teachers working with individuals with special needs were asked to identify the indicators of their describing themselves as innovators, 27 teachers presented one, and five teachers double, in total 37 indicators were presented by the teachers. It was determined that the participant teachers identifying themselves as non-innovative did not present any indicators for this question. The 37 indicators put forward by 32 teachers identifying themselves as innovators were grouped under five main themes and presented in Figure 1. 


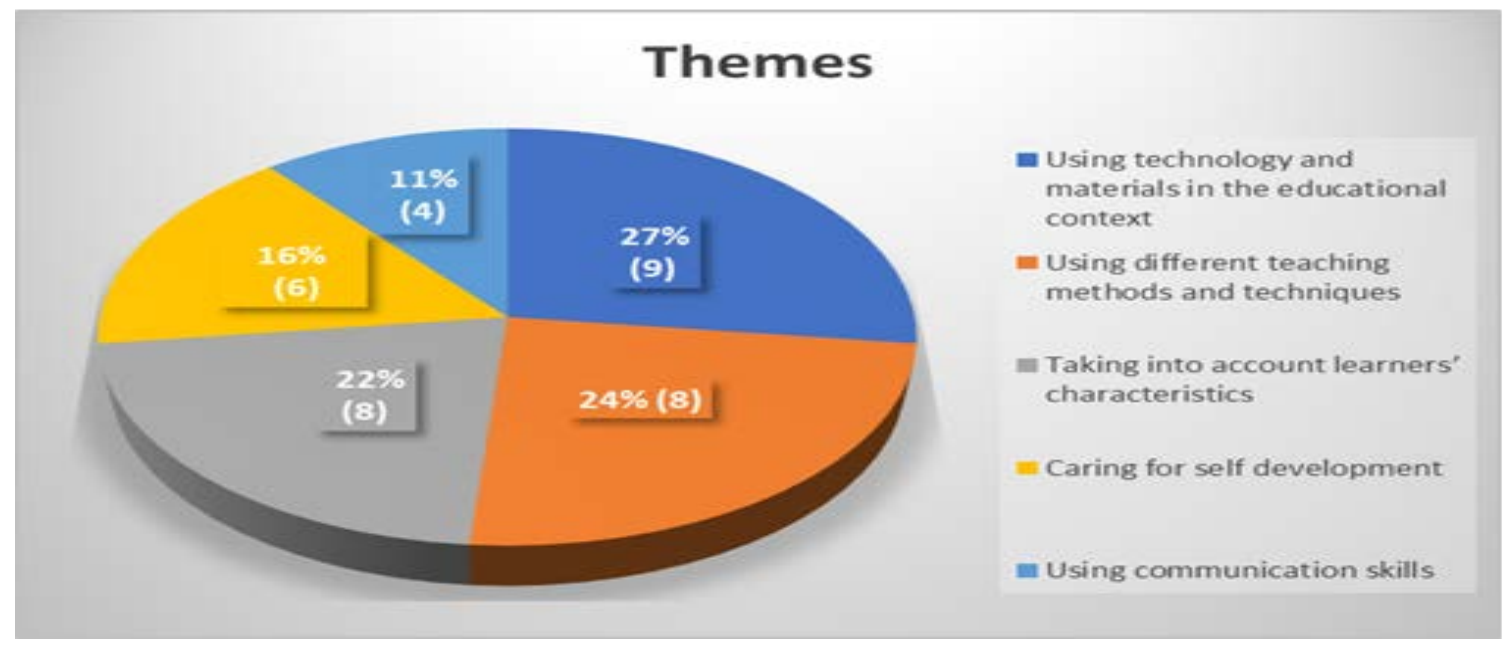

Figure 1. Findings Regarding the Indicators Put Forward by the Teachers Working with Special Needs Individuals for Identifying Themselves Innovative

When Figure 1 is examined, it is determined that teachers mostly think that they are innovative because they use different technologies and materials in the educational context. Teachers' views on this theme are as follows:

When we think of it as an innovation, I think I develop myself in terms of material [T1].

I download images and videos about my lesson on the internet. I edit the materials I download from the Internet according to the student level. While editing, I make sure that shorter sentences and more pictures exist. I find more simulations and game applications related to the subjects and explain them through them. Firstly, I do the activities I create and then I ask students to do it. I organize activities according to students' interests [T8].

I am trying to keep up with technology as much as I can. Since our school is for students with hearing difficulty, I make full use of the internet and smartboards [T20].

Yes, since we are in the digital age, I use all kinds of electronic digital tools. I use all digital materials promptly as I am open to innovations. [T22].

Secondly, it was determined that teachers who work with individuals with special needs think that they are innovative because they use different teaching methods and techniques. Teachers' views on this theme are as follows:

In the teaching and learning process, I want to act with a new way of understanding, leaving aside the classical teaching methods. We aim to raise students who think, question, research and know how to access information. Being a role model and learning while having fun are the qualities I prefer most [T9].

Thanks to my experience and knowledge, I develop various methods and techniques [T11].

We work with many students whose qualifications, skills, and needs are quite different. Therefore, we have to use new teaching methods and techniques for each [T17].

There are webpages that I follow from the internet and I try to learn new methods and techniques to use in my classroom [T19].

We are searching and making use of the latest techniques and methods preferred in education [T34].

Thirdly, it was determined that teachers who work with individuals with special needs think that 
they are innovative because they take into account the characteristics of the learners. Teachers' views on this theme are as follows:

Each student has different needs [T4].

Beyond traditional methods, I think I have been conducting a skill-based education activity to adapt myself to the current era and prepare children for the new century. I focus on improving the handcraft skills of my student. I try to take advantage of music and movement pedagogy. Since I work with children with hearing difficulty, I mostly design my teaching focused on movement and tactile [T13].

Yes, we can easily access information in the digital context. To reveal the student's skills and abilities related to the subject, we must create the necessary conditions in the classroom, in the workshop, and the playground, that enables the individual to learn by doing. I teach the students to use what they have learned in their social life [T18].

As much as I can, I try to implement new practices according to the conditions and needs of the class and the student. During the lesson, I try to involve the student in the process more [T31].

Fourthly, it was determined that teachers working with individuals with special needs thought they were innovative because they attempted to improve themselves. Teachers' views on this theme are as follows:

I read the articles of my professors at the university where I graduated and watch their videos. When I apply it to my students, I get results (positive) when I cannot get results with old methods, I try to find other methods and techniques. I also get ideas from my colleagues. I will continue to work like this [T19].

I am a person with an open mind and love to learn [T21].

I do a lot of research on this subject. I constantly find articles, scientific articles, and materials on how to help children more. I'm trying to fix my deficiencies. I'm trying to increase my knowledge [T24].

I try to be innovative by creating awareness in myself on the subject I feel to be deficient. I am completely creative and trying to make sense of education [T30].

Finally, it was determined that teachers who work with individuals with special needs think that they are innovative because they are caring to use communication skills effectively. Teachers' views on this theme are as follows:

I understand that my students cannot think abstractly by using my empathy ability to count and combine the same colors to be concrete when using mathematical expressions, I also use my ability to drama emotionally (e.g. feelings and reactions) [T4].

I use my skills of communication effectively. With healthy communication, I think a long way can be taken to achieve the desired goal [T5].

My desire and motivation are very good. The teachers and people around me say that I have great energy. I am full of life, as a very good model, I give life energy to people. I empathize very well. I am a very good listener [T16].

I use the skill of empathy [T33].

When the views of teachers who work with individuals with special needs are examined, it is understood that teachers see themselves as innovative because they use technology and materials in the educational environment, apply different teaching methods and techniques, plan their educational practices taking into account the characteristics of learners, make self-improvement 
attempts, and use their communication skills effectively.

\section{The Purposes of Teachers to Apply Innovative Pedagogical Practices}

When the teachers working with individuals with special needs were asked about their purposes of including innovative pedagogical practices, it was determined that 26 teachers identifying themselves as innovative presented only one reason and two teachers gave two reasons each for including innovative pedagogy practices in their lessons. Six teachers' answers could not be placed under any theme within the scope of this question, since two of the research participants did not see themselves as innovators, and four of them touched on adverse environmental conditions outside the scope of the question. 28 teachers who answered in accordance with the scope of this question put forward 30 reasons for including innovative pedagogical practices. The reasons put forward by the teachers were examined and grouped under four main themes, and the findings obtained are shown in Figure 2.

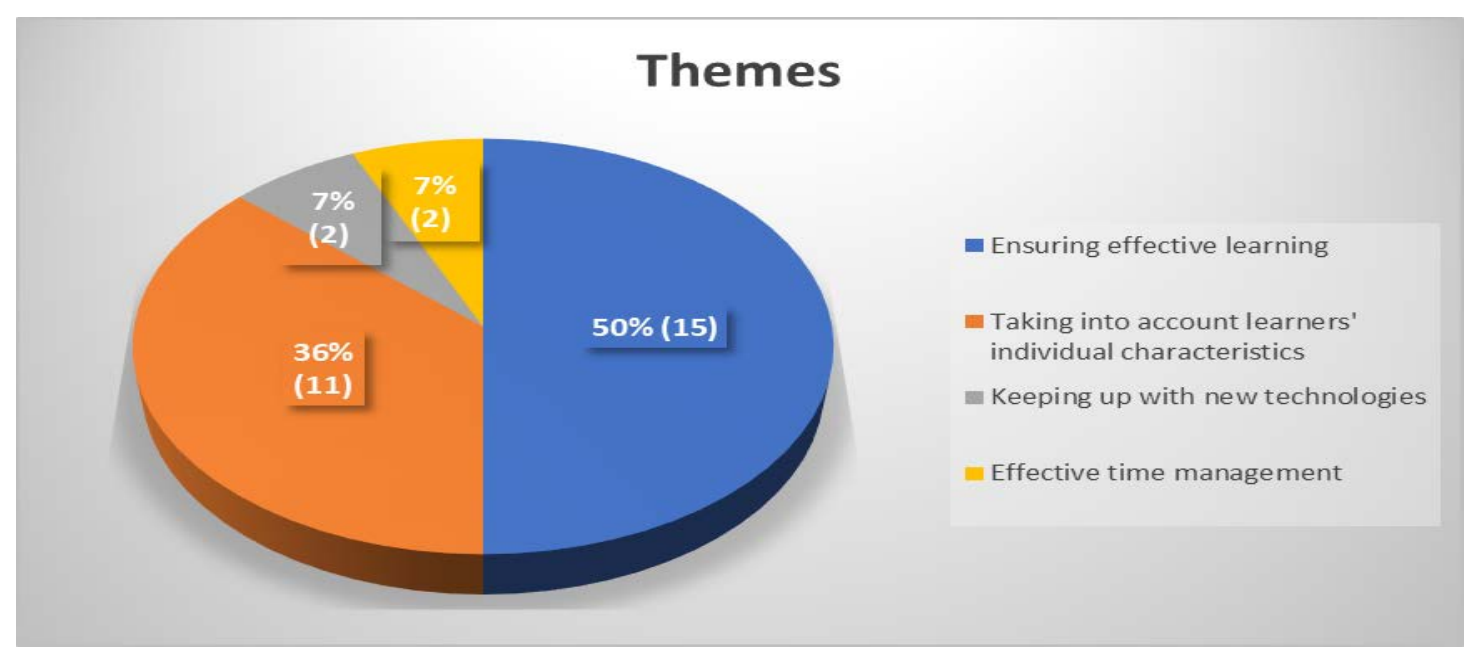

Figure 2. Themes formed based on the reasons put forward by teachers for including innovative pedagogical practices

When Figure 2 is examined, it is determined that teachers mostly act to ensure effective learning for students. Teachers' views on this theme are as follows:

....Because different materials attract students' attention more. Different experiences help children to construct new schemes in their minds [T2].

When it is impossible to show the students the concrete things, using different technological methods helps these students to have a more concrete template in their mind and permanent learning takes place [T13].

I apply it because when the methods and techniques I use do not work, we have to apply to another one sometimes with the desire to get another result (different and better result) [T19].

... Children need tactile materials for reinforcing the learning. Verbal expression is left unsupported. The child grasps better what s/he feels and touches [T33].

When the views of teachers were examined, another reason for teachers to include innovative pedagogy practices was to take students' characteristics and needs into account. Teachers' views on this theme are as follows:

Because each student has different developmental qualities. Each child has some distinct or common characteristics. I examine common studies on social media and the web. I do as much as I can in my classroom [T4]. 
I use visual and concrete materials to ensure that our children learn by doing and experiencing due to their special needs [T18].

Because all of our children behave differently. One method of teaching may not fit another. Taking these into consideration, I search for different techniques and methods [T25].

When there is not enough material for the students with visual difficulty, I develop tactile, tangible sensory materials. It is important to develop material as student-specific material development is really important due to the differences of individuals [T31].

When the views of teachers regarding the reasons for using innovative pedagogy are examined, it is seen that they also touch on the reasons such as keeping up with the latest innovations and effective time management. Teachers' views on these themes are as follows:

Practical applications provide efficiency in terms of time and learning [T3].

We can find more explanatory and broader answers fastly with effective time management [T12].

Using an overhead projector, projector, and smartboard requires me to have all kinds of information. We use it in education by keeping up with technology. I now use a digital pen instead of a wooden pen [T22].

Today, information is developing rapidly and I have to make use of different technologies, methods, and materials to keep up with the latest developments [T34].

When the views of teachers are examined, it is understood that teachers use innovative pedagogical practices in their classrooms to ensure effective and permanent learning in students, to adopt the teaching and learning process in line with the individual characteristics of students with special needs, to use teaching technologies and materials in the classroom and to save time.

\section{Problems Teachers Encounter While Using Innovative Pedagogical Practices}

Finally, when teachers were asked about the problems faced while using innovative pedagogical practices, it was determined that 17 out of 30 teachers mentioned one problem, eight mentioned two problems, and five mentioned three problems. As the answers of four participants were evaluated outside the scope of the question, they could not be placed under any theme. 48 questions put forward by 30 teachers who answered in accordance with the scope of this question were analyzed and gathered under four main themes. The findings obtained are given in Figure 3. 


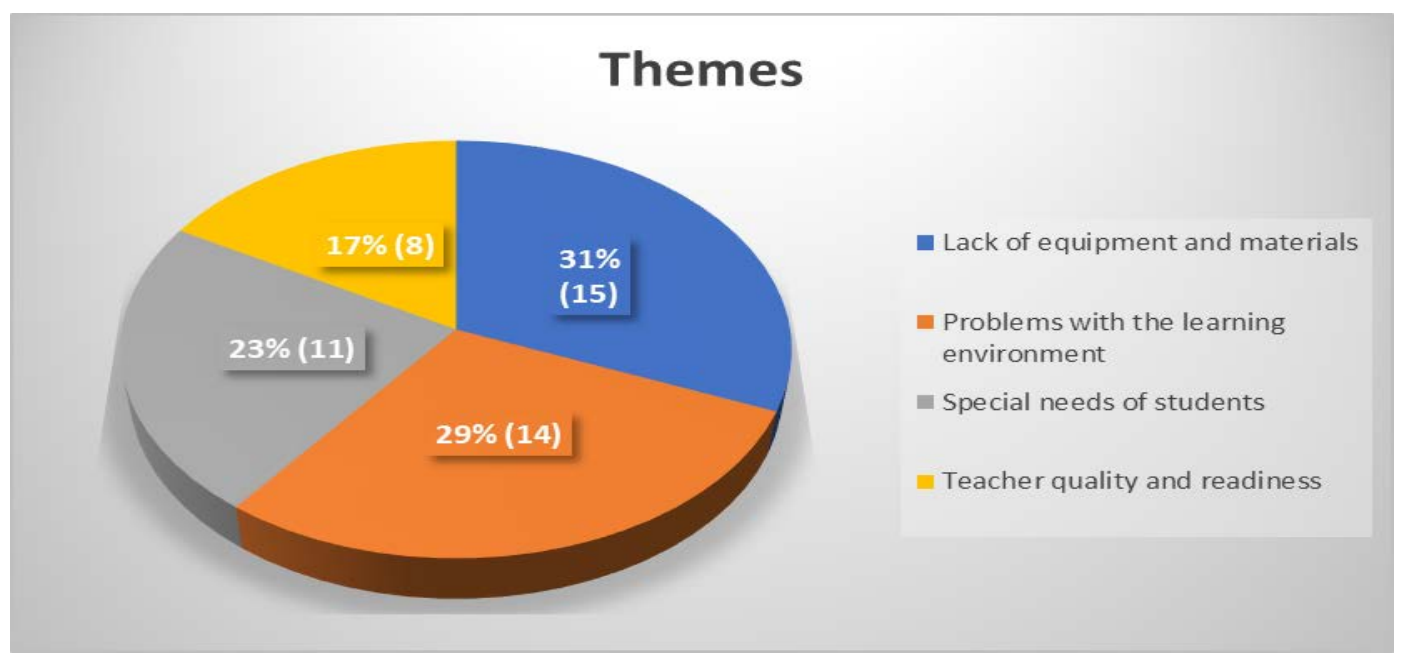

Figure 3. Themes regarding the problems that teachers working with special needs individuals encounter while using innovative pedagogical practices

When Figure 3 is examined, the problem of not having enough equipment and materials in the school environment was determined as the most expressed problem. Teachers' views on this theme are as follows:

You can get a smart board for this. It is not always possible to use our phone or internet [T4].

I use myself more as a material. My communication power. The reason for this is the physical and material inadequacies I mentioned [T5].

There are not enough signs in my lesson. I find it difficult to explain abstract concepts. Since I have a visual and practical lesson, I usually do an activity [T8].

I am also lacking in terms of tools, equipment, and space for the students [T11].

These are the difficulty I faced for my class; the lack of effective methods and materials for our students with double difficulties, methods, and techniques are generally designed for only hearing or only mentally disabled students [T17].

The internet infrastructure is not suitable, the Ministry of National Education supporting internet platform does not allow access to many pages and it is limited [T22].

When the views of teachers were examined, it was determined that the unfavorable and unsuitable learning environment in the school environment was the second most expressed problem by the teachers. Teachers' views on this subject are as follows:

The internet is very slow. There is no fiber cable and some sites are restricted and every information cannot be accessed [T7].

Lack of internet while using the smart board limits my work. If there is an Internet, the video of the subject covered is made to be watched by students on the page (MoNe) and the learning becomes more permanent [T10].

Our most important problem at the middle school for the hearing difficulty is our internet network whose infrastructure cannot be fixed. Without this, we cannot implement many activities without solving this [T14].

Classroom environments are not designed for these students [T32]. 
When the views of were examined, another problem stated by the teachers was that teachers could not accommodate innovative practices due to the special needs of students. Teachers' views on this theme are as follows:

Student levels are not suitable for innovative applications. Student levels, attention spans are very different from each other. Behavior problems are high [T1].

For example, while the student spends time at school with technological tools and equipment, he does not have such a chance at home. Therefore, the learning process can sometimes only be limited to the school [T9].

The most important problem is that students forget the information very quickly. The reason for this is that students have hearing problems [T20].

Since students have visual difficulties, they have problems with the things that they have never known before (internet, etc.), thus problems arise in practice [T27].

The most important problem we encounter while implementing innovative practices in the classroom is the adaptation process of students to innovative practices. There may be a waste of time for students to adapt to these methods [T34].

When the views of teachers were examined, it was stated that teachers' self-readiness was not at the desired level or at low level was another problem expressed by teachers. Teachers' views on this theme are as follows:

We cannot reach a consensus on innovative practices with some of our colleagues [T9].

The most important problem is that I cannot fully comprehend these innovative practices. I feel inadequate at the point of following and implementing the innovations. I think that even though I try to keep up with innovations, I feel that I am not at a sufficient level [T11].

The fact that the management and other colleagues are not ready for these innovative practices can make things more difficult. The lack of applicability of the innovative methods introduced in the curriculum in the field may also be since the old (traditionalist) teachers are not yet ready. Besides, the lack of supporting management to urge the teachers in the school causes the biggest difficulties encountered in this regard [T13].

It is also a big problem that all teachers working in special education schools are not developed in terms of qualifications and that the managers in these schools are not well trained and they are insufficient in special education. [T32].

When the views of teachers are examined, it is observed that while teachers include innovative pedagogical practices in the educational context, they encounter problems such as the lack of sufficient technological tools and materials in the school environment, the lack of physical and economic structure of the schools, the special needs of the students and the low level of teachers' readiness, and these factors are concluded to negatively affects innovative pedagogical practices of the teachers working with students with special needs.

\section{DISCUSSION}

Firstly in this study, it was determined that teachers working with individuals with special needs usually describe themselves as an innovator. Moreover, it was concluded that teachers consider themselves innovators because they use technology and materials in the educational environment, apply different teaching methods and techniques, plan their educational practices considering the 
characteristics of the learners, attempt to improve themselves, and use effective communication skills. The emerging perceptions of teachers as an innovator in the research are also supported by similar studies in the literature (Kocasaraç, 2018; Koehler et al., 2013; Parlar \& Cansoy, 2017; Tournaki \& Lyublinskaya, 2014). For instance; Parlar and Cansoy (2017), Kocasarac (2018), and Suer (2019) in their studies reached the conclusion that teachers consider themselves as innovators above medium level. Innovativeness is the desired qualification for teachers in the 21st-century teaching and learning approach. In terms of innovative educational approaches, teachers are regarded as the most important teaching material and they are expected to be able to use all existing conditions and opportunities effectively in the current conditions and to adapt themselves to the changing situations (Tunkun \& Aksoyalp, 2010).

Innovative pedagogy refers to a more general concept, including the creation and adaptation of ideas, materials, environment, and conditions which can contribute students to gain educational aims and targets (Garcia, 2011). When considered from this aspect, it seems that the teachers working with individuals with special needs try to find out and apply innovative pedagogical practices with the correct sense and purpose. In addition, teachers stated that they use innovative approaches to individualize the learning needs of students with special needs. From this point of view, it is important for the teachers in the study to be aware of innovative approaches that increase both the academic and social success of students with special needs (Boyle, 2013). Innovative approaches play an important role in improving the teaching and training skills of both teachers and students with special needs (Al-Shammari, 2008). Thus, positive interaction is established between students and teachers, and behavioral problems of students are prevented (Boyle, 2013). Consequently, it is of great value to develop teachers' innovative pedagogical practices within the scope of professional development in terms of the progress of children with special needs in all areas of development.

As the second finding of the study, it was concluded that teachers working with students with special needs prefer to use innovative pedagogical practices to provide effective and permanent learning for students in the educational environment, to manage the teaching and learning process addressing the individual characteristics of students with special needs, to use instructional technologies and materials in the classroom and to save on time. Today, the effect of technology shows itself in education as well as in all other fields. The use of smartboards increases in schools, new software is being prepared, and many tools that make life easier for students with special needs are used in classroom teaching. Practices such as distance education and e-learning have become an indispensable part of the teaching period (Polat \& Ozcan, 2014). Particularly in 2020, face to face education was interrupted in our country with the emergence of the new coronavirus called "COVID-19" which first emerged in Wuhan city of China. In this case, concepts such as distance education and e-learning have become essential for students with special needs. Based on the findings of this study, it seems that teachers take advantage of instructional technology and materials in their classrooms. Therefore, it is thought that it would be important to provide comprehensive in-service training on how teachers use technology more effectively in their classrooms and how to prepare e-content for children with special needs. On the other hand, it is important to ensure that all students with special needs have the technology to access distance education in their homes.

As the third finding of the research, it was concluded that while teacher working with students with special needs apply innovative pedagogical practices, they face the problems such as inadequate equipment and materials in the school environment, insufficient physical and 
economic structure of the learning environment and inadequate level of teacher readiness and quality. The teachers working with students with special needs require technological tools and various software programs to facilitate students' learnings (Al-Shammari, 2008). Thanks to these tools and software programs, students with special needs are stated to achieve learning and their existing potential more easily and quickly (Henniger, 2004). When the related studies in the literature were examined, it was observed that teachers frequently face problems related to unfavorable physical and economic structure and insufficient equipment and materials during the educational process (Can \& Çava, 2018; Taşdemir et al., 2018; Yurtseven \& Ergün, 2018). Such problems not only affect the quality of education and educational process but also restrict the innovative pedagogical practices of teachers. A convenient and favorable environment promotes innovative practices (Tidd \& Bessant, 2009). Choi (2004), Usluel and Mazman (2010) stated that the context of learning should be equipped with the required technical support and capacity for the formation and use of innovations. However, the necessary technical and technological equipment is a facilitating factor for innovative applications, it is not sufficient by itself. In this case, educating the labor force in a way that they have the capability of using the existing technology and equipment effectively is also important. Blackhurst (2005) reported that this should be considered in the professional development of teachers working with students with special needs. Tella and Tirri (1999) stated that the introduction of innovative practices in the classroom is also associated with teachers' skills and willingness. Therefore, teachers and other school staff should develop the required skills to provide appropriate technological services to their students. Moreover, teachers working with students with special needs should be trained to maximize their capability of using assistive technology.

Teachers stated that they cannot implement innovative practices in their classrooms because of the students' special needs. Education aims to provide equal opportunities to all individuals, whether they need special education or not. Individuals' need for special education does not prevent them from receiving education in various fields. Innovative approaches such as information and communication technologies, scientific teaching methods, and teachers' following the latest studies with students with special needs help the students with special needs reach equality of opportunity in education, make choices about how to survive, and help them to be economically self-sufficient (

Smith, 2007). Besides, the use of information and communication technologies in the education of individuals with mental, behavioral, emotional behavior problems, learning difficulties, attention deficit and hyperactivity disorder, autism, visual and hearing difficulty improves both academic and social skills of these individuals by providing alternative education opportunities (Zembylas, 2008). Considering these, the reason why teachers express their opinions in this way is due to their not knowing how to use innovative approaches in special education. Teachers are not exposed to innovative information and practices either in their undergraduate education or in their in-service training, and they do not know how to access to this kind of information either. Therefore, it is of great importance for undergraduate and in-service training process of teachers working with students with special needs to include innovative approaches for students with special needs along with the necessary information and technological tools should be provided by the authorities to prevent the inability of children turning into obstacles.

The teachers working with students with special needs are to follow new developments and practices to meet their students' educational needs. In this sense, teachers' knowledge about innovative pedagogical practices could be enhanced by emphasizing the professional development 
of teachers, inservice training programs, seminars and conferences through an expert team. It is also of great value to enrich the content of compulsory special education courses with the innovative pedagogical approaches in teachers training programs. This study is limited to the views of 34 teachers working in special education schools where children with special needs are educated. It is suggested to increase the generalizability of the findings with a wider participant group and qualitative and quantitative research designs. Although teachers' perceptions of innovative approaches are positive, it is also important to investigate how often and in what cases teachers prefer to use innovative practices such as scientific-based practices and technologyoriented learning activities to meet the needs of teachers and students in learning context.

\section{REFERENCES}

Addis, S. (2009). Creativity and innovation. Rough Notes, 152(4), 78-80.

Al-Shammari, Z. (2008). The benefits of technology use in teaching students with special needs. The 5th Congress of Scientific Research Outlook in the Arab World, Scientific Innovation and Sustained Development, October 2008, Morrocco. Retrived from: https://www.academia.edu/.

Blackhurst, E. (2005). Perspectives on applications of technology in the field of learning. Learning Disability Quarterly, 28(2), 175-178. doi: 10.2307/1593622.

Boyle, J. R. (2013). Specialized innovations for students with disabilities. In M. Murphy, S. Redding \& J. Twyman (Eds.), Handbook on innovations in learning (pp. 93-112). Philadelphia, PA: Center on Innovations in Learning, Temple University; Charlotte, NC: Information Age Publishing. Retrieved from: http://www.centeril.org/.

Braun, S., \& Schmidt, A. (2006). Socially aware informal learning support: Potentials and challenges of the social dimension. In Proceedings of the European Conference on Technology-Enhanced Learning (EC-TEL 06), October 2006, Heraklion. Retrieved from: http://citeseerx.ist.psu.edu/viewdoc/download?doi=10.1.1.220.9835\&rep=rep1\&type=pdf\#p age $=137$.

Büyüköztürk, Ş., Çakmak, E. K., Akgün, Ö. E., Karadeniz, Ş., \& Demirel, F. (2013). Bilimsel araştırma yöntemleri [Scientific research methods]. Ankara: Pegem Akademi.

Cagiltay, K., Cicek, F., Karasu, N., Cakir, H., \& Akilli, G. K. (2014, June). Innovative educational technology for special education and usability issues. In International Conference of Design, User Experience, and Usability (pp. 155-163). Springer, Cham.

Can, S., \& Çava, S. (2018). Sınıf öğretmenlerinin görüşlerine göre ilkokulda uygulanan oyun ve fiziki etkinlikler dersinin değerlendirilmesi [Evaluation of the play and physical activities course thought in elementary school on the basis of the classroom teachers' opinions]. Trakya Üniversitesi Eğitim Fakültesi Dergisi, 8(2), 261-273. doi: 10.24315/trkefd.318132.

Choi, J. N. (2004). Individual and contextual dynamics of innovation-use behavior in organizations. Human Performance, 17(4), 397-414. doi: 10.1207/s15327043hup1704_3.

Creswell, J. W. (2017). Nitel araştırmactlar için 30 temel beceri [30 basic skills for qualitative researchs]. Ankara: Anı Yayıncilik.

Deppeler, J. (2010). Professional learning as collaborative inquiry: Working together for impact. (Ed: Forlin, C.). Teacher education for inclusion: changing paradigms and innovative approaches. (First Edition). New York: Routledge.

Dillon, T. (2006). Hail to the thief: The appropriation of in music in the digital age. In K. O'Hara \& B. Brown (Eds.), Consuming music together: Social and collaborative aspects of music consumption technologies. (pp. 289-306). Dordrecht: Springer.

Edwards, A. (2001). Researching pedagogy: A sociocultural agenda. Pedagogy, Culture E Society, 


\section{9(2),161-186. doi: 10.1080/14681360100200111.}

Edwards, S., \& Bone, J. (2012). Integrating peer assisted learning and e-learning: Using innovative pedagogies to support learning and teaching in higher education settings. Australian Journal of Teacher Education, 37(5), 1-12. doi: 10.14221/ajte.2012v37n5.4.

Ekiz. D. (2009). Bilimsel araştırma yöntemleri [Scientific research methods]. Ankara: Anı Yayıncılık.

Erdoğan, D. G., \& Güneş, D. Z. (2013). The relationship between individual innovativeness and change readiness conditions of students attending faculty of education. Procedia-Social and Behavioral Sciences, 106(2), 3033-3040. doi: 10.1016/j.sbspro.2013.12.349.

Furst-Bowe, J. A., \& Bauer, R. A. (2007, Spring). Application of the Baldrige model for innovation in higher education. New Directions for Higher Education, 137, 5-14.

García, L. M. (2011). Encouraging teachers' and students' innovation with the support of teacher learning communities. CEPS Journal: Center for Educational Policy Studies Journal, 1(1), 133152.

Güner Yıldız, N., \& Sazak Pınar, E. (2012). Examining teacher's behavior related to students with special needs in inclusive classrooms. International Online Journal of Educational Sciences, $4(2), 475-488$.

Hasselbring, T. S., \& Glaser, C. H. W. (2000). Use of computer technology to help students with special needs. The Future of Children, 10(2), 102-122. doi: 10.2307/1602691

Henniger, M. L. (2004). The teaching experience: An introduction to reflective practice. New Jersey: Upper Saddle Revier.

Kert, S. B., \& Tekdal, M. (2012). Comparison of individual innovativeness perception of students attending different education faculties. University of Gaziantep Journal of Social Sciences, 11(4), $1150-1161$.

Kocasaraç, H. (2018). Fen ve sosyal bilimler lisesi öğretmenlerinin yenilikçilik durumlarının değerlendirilmesi [Evaluation of innovativeness of science and social sciences high school teachers] (Doktora Tezi). Yükseköğretim Kurulu Ulusal Tez Merkezinden edinilmiştir. (Tez Numaras1: 511297)

Koehler, M. J., Mishra, P., \& Cain, W. (2013). What is technological pedagogical content knowledge (TPACK)?. Journal of Education, 193(3), 13-19. doi: 10.1177/002205741319300303.

Kovacs, H. (2017). Learning and teaching in innovation: Why it is important for education in 21st century. Neveléstudomány, 2, 45-60. doi: 10.21549/NTNY.18.2017.2.4.

Meyen, E., Poggio, J., Seok, S., \& Smith, S. (2006). Equity for students with high-incidence disabilities in statewide assessments: A technology-based solution. Focus on Exceptional Children, 38(7), 1-8. doi: 10.17161/fec.v38i7.6821.

Miles, M. B., Huberman, A. M., \& Saldana, J. (2014). Qualitative data analysis: A method sourcebook. (3rd ed). Thousand Oaks: CA: SAGE.

Murphy, P. (2008) Defining pedagogy. In K. Hall. P. Murphy and J. Soler (Eds.), Pedagogy and practice: Culture and identities. The Open University, SAGE.

Murphy, M., Redding, S., \& Twyman, J. (2014). Handbook on innovations in learning. Philadelphia: Information Age Publishing.

Oblinger, D. G., \& Oblinger, J. L. (2005). Educating the net generation: An educause e-book publication. Retrieved from: http://www.educause.edu/ir/ library/pdf/pub7101.pdf [20/04/07].

OECD, (2020). What does innovation in pedagogy look like? Retrieved from: https://www.oecdilibrary.org/education/what-does-innovation-in-pedagogy-look-like_cca19081-.

Öztürk, Z. Y., \& Summak, M. S. (2014). İlköğretim okulu öğretmenlerinin bireysel 
yenilikçiliklerinin incelenmesi [Investigation of primary school theachers individual innovativeness]. International Journal of Science Culture and Sport, 1(1), 844-853. doi: 10.14486/IJSCS158.

Parlar, H., \& Cansoy, R. (2017). Examining the relationship between teachers' individual innovativeness and professionalism. International Education Studies, 10(8), 1-11. doi: 10.5539/ies.v10n8p1.

Polat, S., \& Özcan, A. (2014). Akilli tahta kullanimiyla ilgili sinif öğretmenlerinin görüşleri [The opinions of elementary school teachers on the use of smart board]. Kastamonu Eğitim Dergisi, 22(2), 439-455.

Pratt, B. (1999). Making it work: Using technology in a classroom for young children with multiple disabilities. Computing Teacher, 26(8), 28-31.

Rawlins, P., \& Kehrwald, B. (2013). Integrating educational technologies into teacher education: A case study. Innovations in Education and Teaching International, 51,207-217

Redding, S., Twyman, J. S., \& Murphy, M. (2013). What is an innovation in learning. Handbook on Innovations in Learning, (pp. 3-14). Temple University, Philadelphia, USA: Center on Innovations in Learning.

Ritchhart, R. (2004). Creative teaching in the shadow of the standards. Independent School, 63(2), 3241.

Rogers, E. M. (1995). Diffusion of Innovations (4th ed.). New York: The Free Press. Retrieved from: https://books.google.com.tr/.

Salaria, N. (2012). Meaning of the term descriptive survey research method. International journal of transformations in business management, 1(6), 1-7.

Silverman, D. (2000). Doing qualitative research. A practical handbook. London: Sage Publications Inc.

Smith, D. (2007). Introduction to special education making a difference. Merrill: Person Education.

Smith, M. K. (2012). What is pedagogy? The encyclopaedia of informal education. Retrieved from: http://infed.org/mobi/what-is-pedagogy/.

Süer, S. (2019). Sınıf öğretmenlerinin yenilikçi pedagoji uygulamalarına ilişkin görüşlerinin değerlendirilmesi [Investigation of classroom teachers' views regarding innovative pedagogical practices] (Doktora tezi). Yükseköğretim Kurulu Ulusal Tez Merkezinden edinilmiştir. (Tez Numaras1: 582578).

Taşdemir, M., Şahin, B. U. C., Taşdemir, Ö. G. F., Kılıç, B. U. E., Dağıstan, B. U. A., \& Dağdelen, B. U. S. (2018). İlkokul İngilizce öğretim programlarına ilişkin öğretmen görüşleri [Teachers' views about primary school English curriculum]. Ĕ̆itim ve Öğretim Araştırmalar Dergisi, 7(3), 121-130.

Tella, S., \& Tirri, K. (1999). Educational innovations in Finnish and European contexts. An analysis of the Aims and Outcomes of the European Observatory of the European Commission. (1994-1998). Opettajankoulutuslaitoksen tutkimusraportti, 200. Retrieved from https://www.researchgate.net/profile/Seppo_Tella/publication/267418535_Educational_Inn ovations_in_Finnish_and_European_Contexts/links/545761e30cf2cf51648087d8.pdf

Tidd J., \& J. Bessant (2009) Managing innovation. (4th Ed). Chichester: John Wiley and Sons.

Tournaki, N., \& Lyublinskaya, I. (2014). Preparing special education teachers for teaching mathematics and science with technology by integrating TPACK framework into the curriculum: A study of teachers' perceptions. Journal of Technology and Teacher Education, 22(2), 243-259.

Tutkun, Ö. F., \& Aksoyalp, Y. (2010). 21. yüzyılda öğretmen yetiştirme eğitim programının boyutları [Dimension of teacher training curricula in the 21st century]. Selçuk Üniversitesi 
Sosyal Bilimler Enstitüsü Dergisi, (24), 361-371.

Usluel, Y. K., \& Mazman, S. G. (2010). Eğitimde yeniliklerin yayılımı, kabulü ve benimsenmesi sürecinde yer alan ögeler: Bir içerik analizi çalışması [The factors process of diffusion of innovations, acceptance or adaptation in educational context: A content analysis study]. Çukurova Üniversitesi Eğitim Fakültesi Dergisi, 39(3), 60-74.

White, S. C., \& Glickman, T. S. (2007, Spring). Innovation in higher education: Implications for the future. New Directions for Higher Education, 137, 97-105.

Will, M. C. (1986). Educating children with learning problems: A shared responsibility. Exceptional Children, 52(5), 411-415. doi: org/10.1177/001440298605200502.

Wolfberg, P., LePage, P., \& Cook, E. (2009). Innovations in inclusive education: Two teacher preparation programs at the San Francisco State University. International Journal of Whole Schooling, 5(2), 16-36.

Yorulmaz, A., Çokçalışkan, H., \& Önal, H. (2017). Determination of classroom pre-service teachers' state of personal innovativeness. Journal of Education and Training Studies.5(1), 28-34. doi:10.11114/jets.v5i1.1947.

Yıldırım, A., \& Şimşek, H. (2011). Sosyal bilimlerde nitel araştırma yöntemleri [Qualitative research methods in the social sciences]. Ankara: Seçkin Yayıncılık.

Yurtseven, R., \& Ergün, M. (2018). İlkokul öğrencilerinin girişimcilik becerilerinin geliştirilmesine yönelik öğretmen görüşleri [Teacher's opinions about development of entrepreneurship skills of primary school students]. International Journal of Social Science Research, 7(1), 118140 . 